\title{
Maatalous ja ilmastonmuutos
}

\section{Martti Esala, Paula Perälä ja Kristiina Regina}

Maa- ja elintarviketalouden tutkimuskeskus, Ympäristöntutkimus, Maaperä ja ympäristö, 31600 Jokioinen,martti.esala@mtt.fi,paula.perala@mtt.fi,kristiina.regina@mtt.fi

Maapallon ilmasto lämpenee kasvihuoneilmiön vaikutuksesta (kuva 1). Ilmiö voimistuu koska kasvihuonekaasuja vapautuu ilmakehään ihmisen toiminnan tuloksena enemmän kuin niitä poistuu. Suomen oloissa tämä tarkoittaa, että vuonna 2050 Rovaniemellä ennustetaan olevan Jyväskylän nykyinen ilmasto (Carter ja Saarikko 1996). Jokioisten kasvukausi vastaisi puolestaan nykyisin Tukholman eteläpuolella vallitsevaa.

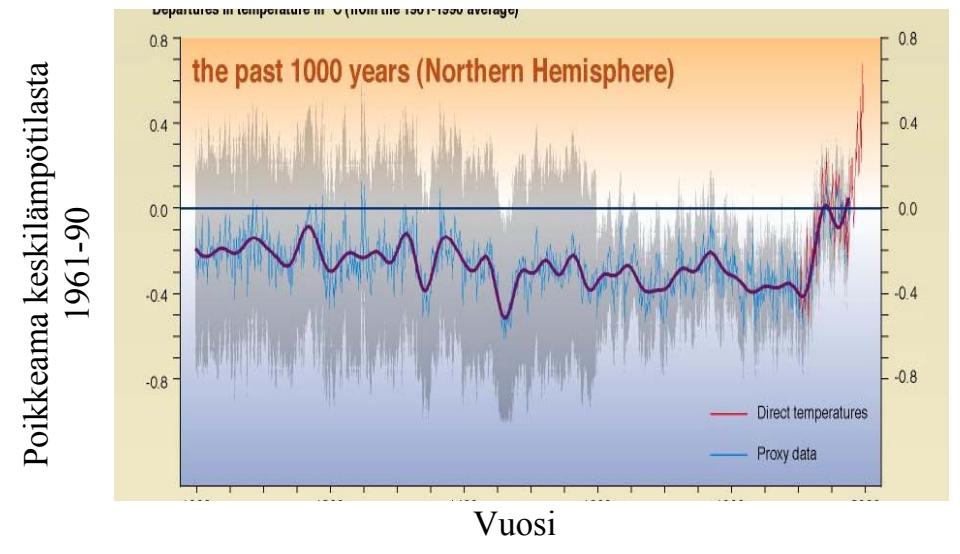

Kuva 1. Maapallon pintalämpötilan muutos viimeisimmän tuhannen vuoden aikana (IPCC 2001)

Ilmastonmuutosta pyritään hillitsemään päästöjä vähentämällä mm. kansainvälisten sopimusten avulla. Myös maataloudella on tässä tehtävää. Maatalouden päästöt ovat noin $9 \%$ Suomen kokonaispäästöistä (Perälä ym. 2004a). Koska nykyisin suunnitelluilla ja sovituilla toimilla kasvihuoneilmiötä pystytään vain hidastamaan, on ihmiskunnalla ja luonnolla edessään väistämättä sopeutuminen muuttuvaan ilmastoon.

Maatalouden päästöjä ovat hiilidioksidi, dityppioksidi ja metaani ja ne syntyvät pääasiassa maaperästä viljelyn vaikutuksesta, kotieläimistä ja niiden lannasta ja energiankäytöstä. Hiilidioksidin kokonaispäästöistä maatalouden osuus on noin $3 \%$, metaanin päästöistä kolmannes ja dityppioksidin yli puolet. Päästöjä vähentävät toimet on kohdistettava näihin lähteisiin. Maataloudella on myös mahdollisuutensa kasvihuoneilmiön hidastamisessa, sillä uusiutuva energia, mm. bioenergia on avainasemassa päästöjä vähennettäessä.

Monet kasvihuonekaasupäästöjen vähentämiseen tähtäävät maatalouteen kohdistuvat toimet ovat linjassa hyvän, ympäristöystävällisen ja taloudellisen viljelyn kanssa (Perälä ym. 2004b). Peltojen viljelyssä on avainasemassa viljelymaan kasvukunnosta, $\mathrm{mm}$. orgaanisen aineksen pitoisuudesta, salaojien toiminnasta, tasapainoisesta lannoituksesta huolehtiminen. Myös muokkauksen vähentäminen ja viljelykierto monivuotisine kasveineen on tärkeätä. Hyvinvoiva kasvusto käyttää ravinteita tehokkaammin, jolloin ravinteiden hävikki pienenee. Erityisesti typen ylilannoitusta tulisi välttää, sillä typpilannoitteista syntyvä dityppioksidi on merkittävä maatalouden kuormituslähde. Turvemaiden viljelystä vapautuu huomattava osuus maatalouden hiilidioksidi- ja dityppioksidipäästöistä, joten niitä tulisi viljellä mahdollisimman kevyesti muokaten esimerkiksi nurmella. Uuden pellon raivaaminen metsästä tai suosta, lisää hehtaarikohtaisia päästöjä eniten, joten sitä tulisi välttää kokonaan. Monivuotisen kasvit ja muokkauksen vähentäminen vähentävät maan orgaanisen aineksen muuttumista hiilidioksidiksi ja lisäävät hiilen sitoutumista maahan. Avokesannointia tulisi välttää, sillä se kuluttaa maaperän hiilivarastoa, eikä hiiltä kerry maahan.

Kotieläintaloudessa on avainasemassa hyvän, tuottoisan eläinaineksen ylläpito, tasapainoinen ruokinta ja lannan käsittely. Erityisesti valkuaisyliruokintaa tulisi välttää, sillä ylimääräinen typpi kulkeutuu virtsaan ja sen mukana ympäristöön. Kun eläin voi ja tuottaa hyvin, ovat tuotetta kohti 
lasketut päästöt alhaisimmat. Tasapainoisen ruokinnan ohella voidaan tavoitteeseen pyrkiä eläinainesta parantamalla jalostuksen avulla. Lannan ja virtsan asianmukainen käsittely tehostavat ravinteiden käyttöä ja pienentävät dityppioksidin ja metaanin päästöjä.

Energian säästäminen tilalla ja uusiutuvan energian käyttö ja tuottaminen sekä jätteiden kierrätys tuovat suoraan myös säästöjä ja antavat lisäansiomahdollisuuksia. Energiaa voidaan tilalla säästää rakennusten lämmityksessä, viljankuivatuksessa, ilmanvaihdossa, kylmäsäilytyksessä, jäähdytyksessä, valaistuksessa ja koneiden polttoaineenkulutuksessa. Rakennusten lämmityksessä tulisi öljyn sijasta käyttää puuta, haketta ja pellettejä. Myös aurinko- ja tuulienergiaa, biokaasua sekä maalämpöä voidaan hyödyntää maatiloilla. Peltoenergiakasvien, kuten ruokohelven, öljykasvien ja energiapajun viljely voivat tuoda vaihtoehtoja ja lisätuloja tiloille.

Ilmastonmuutoksen mahdollisina seurauksina on ennustettu, että maapallon pintalämpötila kohoaa vuoteen 2100 mennessä 1,4 - 5,8 astetta (IPCC 2001). Lämpenemisen seurauksena metsien kasvu kiihtyy, lehtipuut valtaavat alaa havupuilta ja viljasadot kasvavat. Sateet lisääntyvät ja talvet muuttuvat leudommiksi. Napajäätiköt sulavat ja valtamerten pinta kohoaa jopa lähes metrillä. Sään ääri-ilmiöt, kuivuus ja myrskyt lisääntyvät. Suomessa arvioidaan uusimpien arvioiden mukaan lämpötilan nousevan vuoteen 2050 mennessä 1,8 - 5,2 astetta ja sademäärän $4-28 \%$ (Carter ym 2002). Vastaavat lisäykset vuoteen 2080 mennessä ovat 2,4-7,4 astetta ja $6-37 \%$. Suomeen tulee uusia kasvitauteja ja tuholaisia. Kasvukausi pitenee ja talviaika lyhenee, uudet kasvilajit menestyvät meillä, mutta samalla on jalostettava muuttuneeseen ilmastoon sopeutuvia lajikkeita. Hiilidioksidin lisääntyminen lisää kasvien kasvua, mutta samalla saattavat ilmasaasteet, esimerkiksi otsoni aiheuttaa sadonalennuksia. Ravinteiden huuhtoutuminen ja eroosio lisääntyvät ja esimerkiksi savimaiden viljely saattaa vaikeutua. Muutokset kansainvälisessä elintarviketuotannossa saattavat heijastua maataloustuotteista saatavaan hintaan ja niiden kysyntään myös Suomessa. Ilmastomuutokseen sopeutumisessa on monia vastausta vaativia kysymyksiä myös maataloustutkimukselle.

\section{Kirjallisuus}

Carter, T. \& Saarikko, R. 1996. Maatalous. Kuusisto, E., Kauppi, L. \& Heikinheimo, P. 1996 (toim.) Ilmastonmuutos ja Suomi. Yliopistopaino. Helsinki. 127-143.

Carter, T. Bärlund, I., Fronzek, S., Kankaanpää, S. Kaivo-oja, J., Luukkanen, J., Wilenius, M., Tuomenvirta, H., Jylhä, K., Kahma, K., Johansson, M., Boman, H., Launiainen, J., Laurila, T., Lindfors, V., Tuovinen, J-P., Aurela, M. Syri, S., Forsius, M., ja Karvosenoja, N. 2002. The FINSKEN global change scenarios. Teoksessa: J. Käyhkö ja L. Talve (toim.) Understanding the global system - The Finnish Perspective. Finnish Global Change Research Programme FIGARE. Turku 27 40.

IPCC 2001. http://www.ipcc.ch/present/graphics/2001syr/small/05.16.jpg

Perälä, P., Regina, K. \& Esala, M. 2004a. Maatalouden kasvihuonekaasupäästöt. (ks. tämä julkaisu) Perälä, P., Regina, K. \& Esala, M. 2004b. Viljelijä ja ilmastonmuutos - mitä minä voin tehdä omalla tilallani. Maa- ja elintarviketalouden tutkimuskeskus. 16p. 